\title{
In situ food consumption by young-of-the-year Baltic Sea herring Clupea harengus: a test of predictions from a bioenergetics model
}

\author{
Fredrik Arrhenius, Sture Hansson \\ Department of Systems Ecology, Stockholm University, S-10691 Stockholm, Sweden
}

\begin{abstract}
Diurnal variation in stomach fullness of young-of-the-year (YOY) Baltic Sea herring Clupea harengus was used to estimate gut evacuation rates and food consumption rates. The specific food consumption of these fish increased with decreasing body length (25 to $84 \mathrm{~mm}$ ) and increased with increasing temperature, ranging from $17 \%$ of body weight $\mathrm{d}^{-1}$ in summer to $2 \% \mathrm{~d}^{-1}$ at the end of October. The YOY food consumption rates do not differ significantly from consumption rates estimated from growth and a bioenergetics model (Rudstam 1988; Kieler Meeresforsch., Sonderh. 6: 312-322) based on physiological data (respiration rates, egestion and excretion) from adult fish. This result, and our earlier findings, imply that the weakest points in estimating the food consumption of the Baltic Sea herring population are not bioenergetic assumptions, but assumptions related to YOY abundances, mortality rates and growth rates.
\end{abstract}

KEY WORDS: Baltic Sea $\cdot$ Herring $\cdot$ Food consumption $\cdot$ Bioenergetics Evacuation rates

\section{INTRODUCTION}

In a recent article (Arrhenius \& Hansson 1993), we used a combination of population estimates (mainly from reports from the International Council for the Exploration of the Sea, ICES) and a bioenergetics model (Rudstam 1988) to estimate the total food consumption of herring Clupea harengus L. in the Baltic Sea. We estimated that the young-of-the-year (YOY) herring consumed 38 to $76 \%$ of the total consumption of zooplankton by the herring population, making YOY the dominating zooplanktivorous age group. We also concluded that major sources of uncertainty in these estimates were assumptions of the mortality rate and growth rate of the YOY. Another important uncertainty was the bioenergetics model used, since this model was derived from data on older fish only. For YOY yellow perch Perca flavescens Mitchill, Post (1990) reported considerable differences between their actual food consumption and consumption estimated from a bioenergetics model based on data from older fish (between May 20 and July 28, the actual food con- sumption in his study was about twice as high as that estimated from the bioenergetics model).

In their review of problems in the use of bioenergetics models, Hansen et al. (1993) stressed that these models are seldom tested against actual consumption data. Furthermore, they point out that consumption by young fish often are estimated from models based upon data from older fish. The objectives of this study were to address these problems. We determined the in situ food consumption of YOY herring and compared the results with predictions derived from a bioenergetics model developed from data on adult fish (Rudstam 1988).

\section{MATERIALS AND METHODS}

Field consumption. Using small explosive charges ( 15 to $120 \mathrm{~g}$ of Primex $17 \mathrm{~mm}$, Nitro Nobel AB), herring were sampled in a coastal area of the northern Baltic Sea proper (around $58^{\circ} \mathrm{N}, 17^{\circ} \mathrm{E}$ ) during five $24 \mathrm{~h}$ periods in July to October 1992. Collections of fish were 
made at approximately $2 \mathrm{~h}$ intervals over each $24 \mathrm{~h}$ period, and a minimum of 10 fish per length group (class width $5 \mathrm{~mm}$ ) were sampled within $10 \mathrm{~min}$ after each detonation. Captured fish were immediately preserved in $70 \%$ ethanol. Water temperature was measured when sampling.

In the laboratory, the total length of each fish, i.e. length from the tip of the snout to the end of the tail fin, was measured to the nearest $1 \mathrm{~mm}$ and the wet weight (WWT) was measured to the nearest $1 \mathrm{mg}$. Length and weight data were corrected for effects of the ethanol preservation, using our own empirical data [Wet length $=2.28+(0.99 \times$ Ethanol-length $), R=0.99, n=40$ and $W W T=0.02+(1.05 \times$ Ethanol-weight $), R=0.99, n$ $=40$ ). The dry weight (DWT) of the stomach contents were determined to the nearest $1 \mu \mathrm{g}$ (Sartorius micro M3P), after drying at $60^{\circ} \mathrm{C}$ for $3 \mathrm{~d}$ (constant DWT). The DWT was assumed to be $13 \%$ of the WWT for zooplankton (Miliiin 1969). In the laboratory, we also checked the mouth and throat for food remains which could indicate that the fish had vomited as a result of the underwater explosion. We found no such indications.

The stomach contents showed clear diel variation (see Fig. 1) and from these data, daily rations were estimated using the method of Elliott \& Persson (1978). Evacuation rates were calculated from the decline in the stomach content (DWT as proportion of body mass) during non-feeding periods, assuming an exponential evacuation rate (Persson 1986) and no feeding in darkness. We calculated the evacuation rate between approximately $1 \mathrm{~h}$ after sunset and $1 \mathrm{~h}$ before sunrise. For 2 of the dates (August 5-6, September 16-17), the sampling period was shorter than $24 \mathrm{~h}$ due to high wind, necessitating extrapolation of some data (see Fig. 1B, D). The general pattern, with relatively constant daytime stomach fullness, suggests that the errors introduced by these extrapolations are probably small.

Modeled consumption. A bioenergetics model of individual Baltic herring was developed by Rudstam (1988), using software developed by Hewett \& Johnson (1987, 1992). With this kind of model, food consumption is estimated from growth rates, temperature and energy densities of the food and the consumer. The parameters used in Rudstam's model were derived from a variety of sources but in all cases from adult fish. We compared model predictions of daily consumption with in situ food consumption data, estimated as described above. As input parameters to the bioenergetics model, we used date-specific growth rates extrapolated from data from the ICES subdivisions 28 to 29 (Table 2 in Arrhenius \& Hansson 1993). Energy densities for herring and zooplankton follow assumptions made by Arrhenius \& Hansson (1993).

\section{RESULTS AND DISCUSSION}

Stomach content varied in a daily cycle on each sampling date (Fig. 1A to E), being lowest at nighttime, and indicating that herring did not feed in darkness. This suggests a diurnal activity pattern similar to that reported by Westin \& Aneer (1987). As shown in the laboratory by Batty et al. (1990), large herring $(18 \mathrm{~cm})$ may feed in darkness, although at a lower rate than in light. If this was also true for our YOY herring in situ, we have underestimated the gut evacuation rate and hence also the food consumption. High frequencies of entirely or almost empty stomachs at night, however, indicate that the nighttime feeding rate was generally low and that possible errors introduced by this factor

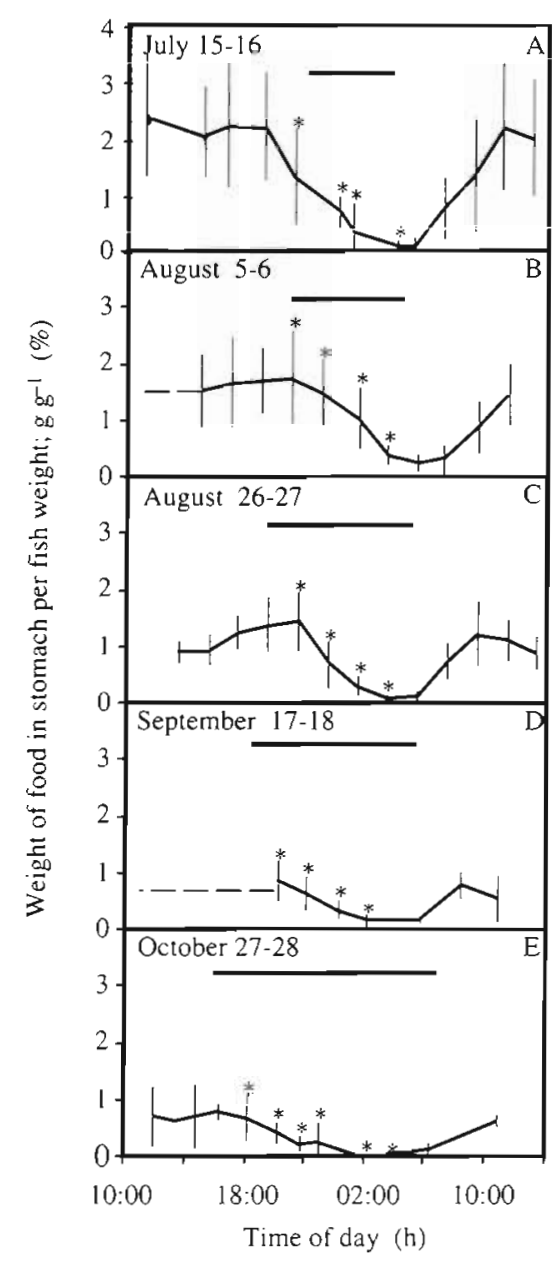

Fig. 1. Clupea harengus. Diel cycle of food content in herring stomachs for 5 sampling dates. Each point represents the average dry weight of stomach content $(\mathrm{g})$ per $g$ dry weight of fish for the 10 fish in each sample at each sampling time. Vertical bars represent $\pm \mathrm{SE}$, based on a sample size of $10 \mathrm{fish}$. (*) Data included in estimating gut evacuation rates. Dashed lines indicate extrapolated data ${ }_{i}$ solid horizontal line indicates the period between sunset and sunrise 
Table 1. Fish length (in $5 \mathrm{~mm}$ intervals), wet weight, daily food ration and evacuation rate of YOY herring in 1992 . The temperature intervals given are for $0-10 \mathrm{~m}$ in July and August and $0-30 \mathrm{~m}$ in September and October, corresponding to the depths occupied by the YOY at the different sampling occasions. The number of fish analysed (1885) is not equal to the number of fish killed at different sampling dates and depths. On the first sampling occasion, 2 stations in the same area but with different depths were sampled, as small fish occurred in shallower water than larger fish (cf. Urho \& Hildén 1990). For comparison with food consumption estimates derived by the bioenergetics model, we assumed that all fish were spawned June 1 and started growth from exogenous feeding on June 15 (Table 2 in Arrhenius \& Hansson 1993). Based on the body weight on June $15(0.0007 \mathrm{~g}$ wet wt; Arrhenius \& Hansson 1993) and the weight at sampling, the bioenergetics model was used to estimate relative food consumption rates ( $P$-values). These $P$-values are estimated food consumption as proportions of estimated maximum food consumptions, given temperature conditions in the area (temperature data from U. Larsson, Dept of Syst. Ecology, Stockholm University, unpubl.). The $P$-values were then used in the bioenergetics model to estimate the specific growth rates given here and to generate predicted food consumption (Fig. 2)

\begin{tabular}{|c|c|c|c|c|c|c|c|c|c|c|c|c|}
\hline \multirow[t]{2}{*}{$\begin{array}{l}\text { Date } \\
\text { Depth }\end{array}$} & \multirow{2}{*}{$\begin{array}{l}\text { Fish } \\
\text { length } \\
\text { interval } \\
\text { (mm) }\end{array}$} & \multirow[t]{2}{*}{$n$} & \multicolumn{2}{|c|}{$\begin{array}{l}\text { Fish length } \\
\text { (mm) }\end{array}$} & \multicolumn{2}{|c|}{$\begin{array}{l}\text { Fish wet } \\
\text { weight (g) }\end{array}$} & \multirow{2}{*}{$\begin{array}{c}\text { Evacuation } \\
\text { rate, } k \\
\left(\mathrm{~h}^{-1}\right)\end{array}$} & \multirow{2}{*}{$\begin{array}{l}\text { Daily food } \\
\text { ration } \\
\text { (wet wt } \% \\
\text { of body wt) }\end{array}$} & \multirow[t]{2}{*}{$P$} & \multirow{2}{*}{$\begin{array}{l}\text { Growth } \\
\left(\mathrm{g} \mathrm{g}^{-1} \mathrm{~d}^{-1}\right)\end{array}$} & \multicolumn{2}{|c|}{$\begin{array}{c}\text { Temperature } \\
\left({ }^{\circ} \mathrm{C}\right)\end{array}$} \\
\hline & & & Mean & SD & Mean & $\mathrm{SD}$ & & & & & Mean & Range \\
\hline \multicolumn{13}{|c|}{ July $16-17$} \\
\hline \multirow[t]{4}{*}{$3 \mathrm{~m}$} & $25-29$ & 95 & 27.3 & 1.3 & 0.040 & 0.012 & 0.35 & 13 & 0.11 & \multirow{3}{*}{0.079} & & \\
\hline & $30-34$ & 110 & 31.9 & 1.4 & 0.089 & 0.025 & 0.39 & 17 & 0.12 & & & \\
\hline & $35-39$ & 83 & 37.1 & 1.3 & 0.20 & 0.044 & 0.38 & 17 & 0.14 & & & \\
\hline & & & & & & & & & & & 17.4 & $16.6-17.7$ \\
\hline \multirow[t]{3}{*}{$10 \mathrm{~m}$} & $30-34$ & 138 & 32.1 & 1.3 & 0.085 & 0.023 & 0.29 & 14 & 0.11 & \multirow{3}{*}{0.065} & & \\
\hline & $35-39$ & 129 & 36.7 & 1.4 & 0.18 & 0.038 & 0.38 & 12 & 0.12 & & & \\
\hline & $40-44$ & 112 & 41.5 & 1.3 & 0.33 & 0.061 & 0.32 & 13 & 0.14 & & & \\
\hline \multicolumn{13}{|c|}{ August $5-6$} \\
\hline \multirow[t]{5}{*}{$10 \mathrm{~m}$} & $30-34$ & 60 & 32.6 & 1.4 & 0.11 & 0.030 & 0.24 & 8.3 & 0.12 & \multirow{5}{*}{0.057} & \multirow{5}{*}{16.5} & \multirow{5}{*}{$11.9-19.1$} \\
\hline & $35-39$ & 89 & 37.2 & 1.3 & 0.22 & 0.045 & 0.26 & 13 & 0.13 & & & \\
\hline & $40-44$ & 104 & 42.1 & 1.3 & 0.39 & 0.067 & 0.23 & 10 & 0.15 & & & \\
\hline & $45-49$ & 110 & 47.0 & 1.5 & 0.59 & 0.087 & 0.21 & 8.8 & 0.16 & & & \\
\hline & $50-55$ & 87 & 52.1 & 1.3 & 0.86 & 0.087 & 0.27 & 12 & 0.18 & & & \\
\hline \multicolumn{13}{|c|}{ August $26-27$} \\
\hline $15 \mathrm{~m}$ & $45-49$ & 82 & 47.6 & 1.3 & 0.61 & 0.084 & 0.29 & 14 & 0.14 & \multirow{4}{*}{0.042} & \multirow{4}{*}{15.0} & \multirow{4}{*}{$10.6-16.6$} \\
\hline & $50-54$ & 125 & 52.3 & 1.3 & 0.86 & 0.081 & 0.33 & 12 & 0.15 & & & \\
\hline & $55-59$ & 130 & 57.0 & 1.3 & 1.2 & 0.12 & 0.21 & 11 & 0.16 & & & \\
\hline & $60-64$ & 108 & 61.8 & 1.4 & 1.5 & 0.13 & 0.26 & 11 & 0.17 & & & \\
\hline \multicolumn{13}{|c|}{ September 17-18 } \\
\hline \multirow[t]{3}{*}{$20 \mathrm{~m}$} & $60-64$ & 54 & 62.2 & 1.3 & 1.4 & 0.12 & 0.20 & 6.6 & 0.17 & \multirow{3}{*}{0.036} & \multirow{3}{*}{13.2} & \\
\hline & $65-69$ & 62 & 67.0 & 1.4 & 1.6 & 0.12 & 0.19 & 5.0 & 0.17 & & & $8.7-13.2$ \\
\hline & $70-74$ & 55 & 71.5 & 1.3 & 2.0 & 0.15 & 0.28 & 7.4 & 0.18 & & & \\
\hline October & -28 & & & & & & & & & & & \\
\hline $35 \mathrm{~m}$ & $70-74$ & 39 & 72.0 & 1.4 & 1.9 & 0.336 & 0.16 & 2.1 & 0.14 & & & \\
\hline & $75-79$ & 50 & 76.9 & 1.5 & 2.5 & 0.350 & 0.20 & 3.5 & 0.16 & 0.025 & 8.7 & $8.5-8.7$ \\
\hline & $80-84$ & 63 & 81.9 & 1.4 & 3.0 & 0.387 & 0.23 & 3.6 & 0.17 & & & \\
\hline Total no. & fish: & 1885 & & & & & & & & & & \\
\hline
\end{tabular}

into our daily consumption rate estimates are small. Instantaneous per hour gut evacuation rates (Elliott \& Persson 1978) ranged from 0.39 to 0.16 , being higher in summer when water temperature was high, and lower in autumn (Table 1). This was expected, since evacuation rates depend mainly on the water temperature (Elliott \& Persson 1978). Effects on evacuation rates of fish size, food particle size and the frequency of feeding are less significant than temperature (Elliott 1972.
De Silva \& Balbontin 1974), although food quality may influence the rate of evacuation: food with low energy density is evacuated faster than food with a high energy density (Jobling 1980). In our herring, gut content was exclusively zooplankton, with usually $>95 \%$ crustaceans, and variation between sampling dates thus unlikely to be caused by differences in diet.

The daily food consumption of YOY herring varied from about $17 \%$ of the body weight for small juveniles 


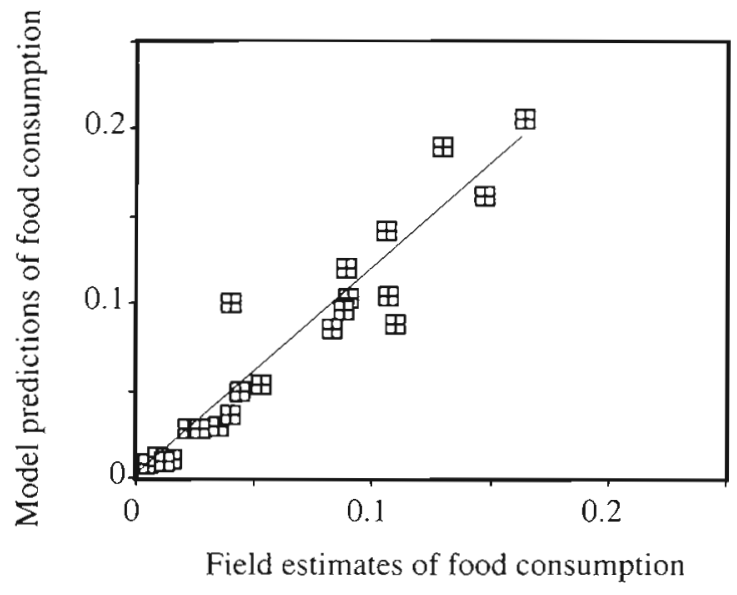

Fig. 2. Clupea harengus. Food consumption (g wet weight) predicted by the bioenergetics model plotted against the in situ data. The slope and the intercept do not differ significantly from 1 and 0 respectively $\left[\mathrm{n}=21, \mathrm{r}^{2}=0.89\right.$; slope $( \pm 95 \% \mathrm{CI})=1.19 \pm 0.20(\mathrm{p}=0.07)$ and intercept $( \pm 95 \% \mathrm{Cl})=$ $-0.0003 \pm 0.008(p=0.97)]$

in the summer to $2 \%$ for larger juveniles in late autumin (Table 1). The specific food consumption decreased with increasing body size [Linear regression (SYSTAT 1992); $\mathrm{n}=21, F=6.12, \mathrm{p}=0.02$ ] and increased with increasing temperature $(n=21, F=5.05$, $p=0.04$ ). It is reasonable to assume, however, that food consumption is also influenced by other factors, e.g. the abundance of zooplankton, but at this stage, data do not permit an analysis of interactions between water temperature, fish size, zooplankton abundance and the food consumption of YOY herring.

The agreement between food consumption rates estimated from the in situ study and from the bioenergetics model was evaluated using linear regression analysis (SYSTAT 1992). Data from the field estimates were used as the independent variable and data from model predictions as the dependent variable. There was no significant difference between the model and field estimates of food consumption (Fig. 2). Thus the bioenergetics model for herring, based on data from adult fish, does not predict consumption rates significantly different from those estimated for YOY fish in situ. Although we have relatively few data points, and the power of our test, consequently, is relatively low, the result indicates that the bioenergetics model gives a reasonable estimate of the food consumption by individual young herring. The $95 \%$ confidence interval of the slope is 0.99 to 1.39 , which implies that the bioenergetics model predicts food consumptions of YOY herring that differ less than $40 \%$ from our in situ estimates. If the bioenergetics model is biased, it probably overestimates the food consumption.

There are some literature data on specific consumption rates similar to those we observed. De Silva \& Bal- bontin (1974) reported values between 12 and $4 \%$ depending on temperature and length of the fish, but these authors made their experiments on North Atlantic herring and these were considerable larger ( 6 to $18 \mathrm{~g} \mathrm{WWT}$ ) than ours (0.04 to $3 \mathrm{~g}$ WWT). In the Baltic, Franek (1988) has calculated values between 19 and $10 \%$ for juvenile herring, but the method used is not clear to us.

Due to weather conditions and the distributions of fish, the sampling site varied among the five $24 \mathrm{~h}$ periods but all sites were located within $30 \mathrm{~km}$ of each other and the fish thus, in a general sense, belonged to the same population. It is possible, though, that fish of this young age are relatively stationary and that growth might have differed slightly between areas. However, since most of the consumed food is used for respiration, excretion and egestion, only a minor part is transferred into growth. A growth rate difference of e.g. $20 \%$ thus corresponds to a consumption rate difference of only $7.7 \%$ (estimates based on the bioenergetics model; Rudstam 1988), assuming a fish size of $50 \mathrm{~mm}$, water temperature of $16^{\circ} \mathrm{C}$ and a daily growth rate of 0.0157 and $0.0188 \mathrm{~g} \mathrm{~g}^{-1} \mathrm{~d}^{-1}$ respectively).

In our food consumption estimations with the bioenergetics model, we used growth data from ICES-subdivisions 28 to 29 instead of data from subdivision 27 , where the sampling actually took place. This was done since growth data from subdivisions 28 to 29 were in better agreement with the temporal development of the YOY length distribution in our samples.

Our results on YOY herring are different from those presented by Post (1990), who found that a bioenergetics model parameterized with data from adult yellow perch Perca flavescens was not applicable for small YOY. Studies on juvenile walleye Stizostedion vitreum vitreum (Mitchell) by Fox (1991) and Madon \& Culver (1993) gave variable results but show that bioenergetics models, based on data from adult walleye, may give inaccurate prediction of consumption of YOY.

It is not clear to us why the same bioenergetics model can be used for both YOY and adults of some species but not for others. There are reasons to expect that bioenergy levels of larval and very young fish might differ from that of adults. Post (1990) showed that effects of activity had a stronger influence on the total metabolism in small YOY yellow perch than in larger fish. Another potential difference in metabolism between small and large fish could be related to the standard metabolic rate $(R)$, which declines as the fish increases in size $(W)$. In bioenergetics models, the exponent $b$ in this relationship $\left(R=a W^{b}\right)$ is usually assumed constant (around 0.8; Winberg 1956, Fry 1957 , Brett \& Groves 1979 ), but as shown by Giguère et al. (1988), Wieser (1991) and Kamler (1976), this exponent may be higher for larvae than for older fish. Since 
there are hardly any in situ estimates of food consump. tion by adult Baltic herring available, we cannot evaluate whether these or similar complications affect the possibility of using the bioenergetics model for herring on both YOY and older fish.

In our previous analysis of total food consumption by herring in the Baltic Sea (Arrhenius \& Hansson 1993), we showed that YOY fish were the dominating zooplanktivorous age group and that errors in abundance assessments or demographic assumptions for these could introduce biases of a factor of 2 or more. In estimating the total food consumption by Baltic herring. assumptions and errors in abundances and demographic assumptions are thus potentially more important than the errors in the bioenergetics model, which we in this paper have shown to be less than $40 \%$ of in situ estimates of food consumption.

Acknowledgements. We are grateful to Gunnar Aneer, Ragnar Elmgren and anonymous reviewers for valuable criticisms on earlier versions of the manuscript. Sture Nellbring. Markus Nikula and Joakim Westberg helped in the field. Financial support was provided by the Swedish Natural Science Research Council, Hierta-Retzius foundation, Alice \& Lars Siléns fund, Stockholm Centre for Marine Research and Nitro Nobel AB

\section{LITERATURE CITED}

Arrhenius, F., Hansson, S. (1993). Food consumption of larval young and adult herring and sprat in the Baltic Sea. Mar. Ecol. Prog. Ser. 96: 125-137

Batty, R. S., Blaxter, J. H. S., Richard, J. M. (1990). Light intensity and the feeding of herring Clupea harengus. Mar. Biol. 107: 383-388

Brett, J. R., Groves, T. D. D. (1979). Physiological energetics In: Hoar, W. S., Randall, D. J., Brett, J. R. (ed.) Fish physiology, Vol. 8. Academic Press, New York, p. 279-352

De Silva, S. S., Balbontin, F. (1974). Laboratory studies on food intake, growth and food conversion of young herring, Clupea harengus (L.). J. Fish Biol. 56: 645-658

Elliott, J. M. (1972). Rates of gastric evacuation in brown trout Salmo trutta L. Freshwat. Biol. 5: 287-303

Elliott, J. M., Persson, L. (1978). The estimation of daily rates of food consumption for fish. J. Anim. Ecol. 47: 977-991

Fox, M. G. (1991). Food consumption and bioenergetics of young-of-the-year walleye (Stizostedion vitreum vitreum) - model predictions and population density effects. Can J. Fish. Aquat. Sci. 48: 434-441

Franek, D. (1988). O+ smelt (Osmerus eperlanus L.) and herring (Clupea harengus L.) in the food chain of the Barter

This article was submitted to the editor
Bodden. Comm. Meet. int. Coun. Explor. Sea C.M.-ICES 1988/J:13: $1-16$

Fry, F. E. J. (1957). The aquatic respiration of fish. In: Brown, M. E. (ed.) The physiology of fishes, Vol. I. Academic Press, New York, p. 1-63

Giguère, L. A., Côté, B., St-Pierre, J.-F. (1988). Metabolic rates scale isometrically in larval fishes. Mar. Ecol. Prog. Ser 50: $13-19$

Hansen, M. J., Boisclair, D., Brandt, S. B., Hewatt, S. W. Kitchell, J. F., Lucas, M. C., Ney, J. J. (1993). Applications of bioenergetics models to fish ecology and management: Where do we go from here? Trans. Am. Fish. Soc. 122 1019-1030

Hewett, S. W., Johnson, J. L. (1987). A generalized bioenergetics model of fish growth for microcomputers. University of Wisconsin Sea Grant Technical Report No. WIS-SG-87 245, Madison

Hewett, S. W., Johnson, J. L. (1992). Fish bioenergetics model 2 . An upgrade of a generalized bioenergetics model of fish growth for microcomputers, 2nd edn. University of Wisconsin Sea Grant Technical Report No. WIS-SG-92-250, Madison, p. 1-79

Jobling, M. (1980). Gastric evacuation in plaice, Pleuronectes platessa L.: effects of dietory energy level and food consumption. J. Fish Biol. 17: 187-196

Kamler, E. (1976). Variability of respiration and body composition during early development stages of carp. Pol. Arch. Hydrobiol. 23: 431-485

Madon, S. P., Culver, D. A. (1993). Bioenergetics model for larval and juvenile walleyes: an in situ approach with experimental ponds. Trans. Am. Fish. Soc. 122: 797-813

Mullin, M. M. (1969). Production of zooplankton in the ocean the present status and problems. Oceanogr. mar. Biol. Rev. 7: $293-310$

Persson, L. (1986). Patterns of food evacuation in fishes: a critical review. Environ. Biol. Fish. 16: 51-58

Post, J. R. (1990). Metabolic allometry of larval and juvenile yellow perch (Perca flavescens): in situ estimates and bioenergetics models. Can. J. Fish. Aquat. Sci. 47: 554-560

Rudstam, L. G. (1988). Exploring the dynamics of herring consumption in the Baltic: applications of an energetic model of fish growth. Kieler Meeresforsch., Sonderh. 6: 312-322

SYSTAT (1992). SYSTAT: Statistics, Version 5.2. SYSTAT Inc., Evanston, IL

Urho, L., Hildén, M. (1990). Distribution patterns of Baltic herring larvae, Clupea harengus, L., in the coastal waters off Helsinki, Finland. J. Plankton Res. 12: 41-54

Westin, L., Aneer, G. (1987). Locomotory activity patterns of nineteen fish and five crustacean species from the Baltic Sea. Environ. Biol. Fish 20: 49-65

Wieser, W. (1991). Limitations of energy acquisition and energy use in small poikilotherms: evolutionary implications. Funct. Ecol. 5: 234-240

Winberg, G.G. (1956). Rate of metabolism and food requirement of fishes. Nauch. Tr. Beloruss. Gos. Univ. Minsk (in Russian). Translated (1960) Fish. Res. Bd Can. Trans. Ser. 194: $1-202$

Manuscript first received: November 12, 1993

Revised version accepted: May 29, 1994 


\section{Erratum}

\section{Re: F. Arrhenius, S. Hansson}

Mar. Ecol. Prog. Ser. 110: 145-149 (1994)

- In this article, we used growth rates and a bioenergetics model to estimate the food consumption of young-of-the-year herring Clupea harengus L. in the Baltic Sea. We compared model predictions with in situ consumption estimates, and concluded that both models gave similar results. The bioenergetics estimates were, however, incorrect and Fig. 2 was wrong. It is not clear to us why the erroneous results were produced, but the correct values from the bioenergetics model are about twice as high as our in situ values for food consumption. These values are shown in the corrected Fig. 2.

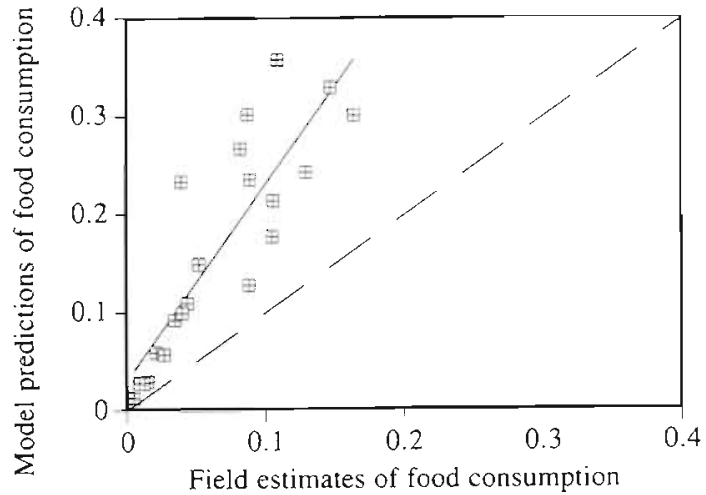

Fig. 2. Clupea harengus. Food consumption (g wet weight) predicted by the bioenergetics model plotted against the in situ data. The dashed lire is the 1:1 relation. The linear regression of the data points is $y=0.032+1.98 x_{i} \mathrm{R}=0.86$

- Two columns in Table 1 were also incorrect. Corrected data are in the columns $P$ and Growth

\begin{tabular}{|c|c|c|c|c|c|c|c|c|c|c|c|c|}
\hline \multirow[t]{2}{*}{$\begin{array}{l}\text { Date } \\
\text { Depth }\end{array}$} & \multirow{2}{*}{$\begin{array}{c}\text { Fish } \\
\text { length } \\
\text { interval } \\
(\mathrm{mm})\end{array}$} & \multirow[t]{2}{*}{$\mathrm{n}$} & \multicolumn{2}{|c|}{$\begin{array}{l}\text { Fish length } \\
(\mathrm{mm})\end{array}$} & \multicolumn{2}{|c|}{$\begin{array}{l}\text { Fish wet } \\
\text { weight (g) }\end{array}$} & \multirow{2}{*}{$\begin{array}{c}\text { Evacuation } \\
\text { rate }(k) \\
\left(\mathrm{h}^{-1}\right)\end{array}$} & \multirow{2}{*}{$\begin{array}{l}\text { Daily food } \\
\text { ration } \\
\text { (wet wt, \% } \\
\text { of body wt) }\end{array}$} & \multirow[t]{2}{*}{ P } & \multirow{2}{*}{$\begin{array}{l}\text { Growth } \\
\left(g^{-1} d^{-1}\right)\end{array}$} & \multicolumn{2}{|c|}{$\begin{array}{c}\text { Temperature } \\
\left({ }^{\circ} \mathrm{C}\right)\end{array}$} \\
\hline & & & Mean & SD & Mean & $\mathrm{SD}$ & & & & & Mean & Range \\
\hline \multicolumn{13}{|c|}{ July $16-17$} \\
\hline $3 \mathrm{~m}$ & $25-29$ & 95 & 27.3 & 1.3 & 0.040 & 0.012 & 0.35 & 13 & 0.26 & 0.076 & \multirow{7}{*}{17.4} & \multirow{7}{*}{$16.6-17.7$} \\
\hline & $30-34$ & 110 & 31.9 & 1.4 & 0.089 & 0.025 & 0.39 & 17 & 0.31 & 0.085 & & \\
\hline & $35-39$ & 83 & 37.1 & 1.3 & 0.20 & 0.044 & 0.38 & 17 & 0.38 & 0.093 & & \\
\hline & & & & & & & & & & & & \\
\hline \multirow{3}{*}{$10 \mathrm{~m}$} & $30-34$ & 138 & 32.1 & 1.3 & 0.085 & 0.023 & 0.29 & 14 & 0.31 & 0.084 & & \\
\hline & $35-39$ & 129 & 36.7 & 1.4 & 0.18 & 0.038 & 0.38 & 12 & 038 & 0.092 & & \\
\hline & $40-44$ & 112 & 41.5 & 1.3 & 0.33 & 0.061 & 0.32 & 13 & 0.43 & 0.097 & & \\
\hline \multicolumn{13}{|c|}{ August $5-6$} \\
\hline $10 \mathrm{~m}$ & $30-34$ & 60 & 32.6 & 1.4 & 0.11 & 0.030 & 0.24 & 8.3 & 0.26 & 0.048 & \multirow{5}{*}{16.5} & \multirow{5}{*}{$11.9-19.1$} \\
\hline & $35-39$ & 89 & 37.2 & 1.3 & 0.22 & 0.045 & 0.26 & 13 & 0.29 & 0.059 & & \\
\hline & $40-44$ & 104 & 421 & 1.3 & 0.39 & 0.067 & 0.23 & 10 & 0.33 & 0.061 & & \\
\hline & $45-49$ & 110 & 47.0 & 1.5 & 0.59 & 0.087 & 0.21 & 8.8 & 0.36 & 0.062 & & \\
\hline & $50-55$ & 87 & 52.1 & 1.3 & 0.86 & 0.087 & 0.27 & 12 & 0.39 & 0.063 & & \\
\hline \multicolumn{13}{|c|}{ August $26-27$} \\
\hline $15 \mathrm{~m}$ & $45-49$ & 82 & 47.6 & 1.3 & 061 & 0.084 & 0.29 & 14 & 0.29 & 0.044 & \multirow{4}{*}{15.0} & \multirow{4}{*}{$10.6-16.6$} \\
\hline & $50-54$ & 125 & 52.3 & 1.3 & 086 & 0.081 & 0.33 & 12 & 0.31 & 0.045 & & \\
\hline & $55-59$ & 130 & 57.0 & 1.3 & 1.2 & 0.12 & 0.21 & 11 & 0.34 & 0.046 & & \\
\hline & $60-64$ & 108 & 61.8 & 1.4 & 1.5 & 0.13 & 0.26 & 11 & 0.35 & 0.046 & & \\
\hline \multicolumn{13}{|c|}{ September $17-18$} \\
\hline $20 \mathrm{~m}$ & $60-64$ & 54 & 62.2 & 1.3 & 1.4 & 0.12 & 0.20 & 6.6 & 0.30 & 0.035 & \multirow{3}{*}{13.2} & \multirow{3}{*}{$8.7-13.2$} \\
\hline & $65-69$ & 62 & 67.0 & 1.4 & 1.6 & 0.12 & 0.19 & 5.0 & 0.30 & 0.035 & & \\
\hline & $70-74$ & 55 & 71.5 & 1.3 & 2.0 & 0.15 & 0.28 & 7.4 & 0.32 & 0.035 & & \\
\hline \multicolumn{13}{|c|}{ October $27-28$} \\
\hline $35 \mathrm{~m}$ & $70-74$ & 39 & 72.0 & 1.4 & 1.9 & 0.336 & 0.16 & 2.1 & 0.27 & 0.020 & \multirow{3}{*}{8.7} & \multirow{3}{*}{$8.5-8.7$} \\
\hline & $75-79$ & 50 & 769 & 1.5 & 2.5 & 0.350 & 0.20 & 3.5 & 0.28 & 0.020 & & \\
\hline & $80-84$ & 63 & 81.9 & 1.4 & 3.0 & 0.387 & 0.23 & 3.6 & 0.29 & 0.020 & & \\
\hline \multicolumn{2}{|c|}{ Total no. of fish: } & 1885 & & & & & & & & & & \\
\hline
\end{tabular}

